\title{
Opinions of English Major Students about Their Departments' Websites
}

\author{
Bugra Zengin \\ Namik Kemal University, Turkey \\ Arda Arikan \\ Akdeniz University, Turkey \\ Duygu Dogan \\ Namik Kemal University, Turkey
}

\begin{abstract}
University websites serve as sharing information with students whether prospective or enrolled. Often, before entering their departments, students visit them to have an idea as to what it would be like to be a part of that university and/or department. In that sense, websites help students in deciding whether the university matches their expectations. After enrollment, websites start to serve as their representative and an interactive ground for students, academics, and administrative personnel of the university. Because schools exist for students, their opinions matter. This study aimed to have students' opinions of their departmental websites. For the purposes of this study, students of English or related majors (i.e. English language teaching, English linguistics, English language and literature, translation studies, American culture and literature) were sent a questionnaire to find out their opinions of their departments' official websites. The results suggest that there are a number of areas for universities and departments to improve their websites to promote themselves in a more realistic manner that suits needs of their students.
\end{abstract}

Keywords: Web design; University websites; Academic resumes; Educational marketing; Evaluation of websites; Higher education

\section{Introduction}

There are 104 state universities, 62 foundation-owned higher education institutions, and 7 private vocational schools (http://www.yok.gov.tr) in Turkey. However, many homepages and websites of the Turkish universities or their departments have not been very active; even worse, there are many problems with them such as dysfunctional links or existence of missing information. Despite there exists improvement, some problems still remain such as design and layout problems; for instance, those related to information overload, inadequacy of negative space (space around and between the subjects of an image), inappropriate color scheme, or typography, you can see pages relating to announcements or resumes which have not been updated. Especially important are the resumes of academics, recruited by the school, the very existence of which is the student who demands accountability as to the qualifications of the teaching staff including the question as to which course is offered by which academicians with what qualifications based on what criteria. 


\section{Theoretical Framework}

As part of the new technologies, the Internet and websites are one of the fastest and most effective ways of communication. Compared to traditional ways of communication, Internetbased communication may provide information in either synchronous or asynchronous way. In synchronous communication, the response is received at the same time as the message is sent, that means interaction occurs at the same time like in electronic chat (Ohlund et al., 2000). In asynchronous communication, location and time of each interaction change. Hence, a caller system is needed to receive the message back at a later time. Websites as a part of Internetbased communication keep several advantages of new technologies. Web transmits messages (or information) either to one receiver or more people. Since it is asynchronous, it does not allow real interaction. Its most significant advantage however is its speed, its use in the global environment, and its relatively low cost (Bonchek, 1997, cited in Timisi 2003). The multichannel environment may facilitate the negotiations between the organization and the public (Kent \& Taylor, 1998).

Websites are suitable for two-way communication. As Kent and Taylor (1998) state the web is "an excellent information dissemination tool and useful for getting a message out" (p.325). As an organization, what you would like to announce, what you will let your stakeholders learn about yourself and how much information you will reveal on the website is manipulated by yourself. On the other hand, your stakeholders expect to acquire as much information as they could through this web source.

From the point of this study, students as stakeholders will ask for genuine information about the quality of education, courses, programs as well as on-campus accommodation, social life, and other opportunities offered by the university. While they are seeking answers for their questions on the Internet, the university tries to capture the interest of highly remarkable young talents who have taken high scores from the University Entrance Exam and still in quest of the right university to be enrolled/to make his/her choices in the preference sheet.

University websites with their rich and updated content besides their designs and user-friendly interfaces form a positive image in students' minds while providing detailed information about their educational activities and academic assets. The key point where the university website disseminates information given by the service provider (the university) to the stakeholders (the students) is the quality of that information. Dragulanescu (2002) points out that the information is high quality "if the provider has taken into consideration both the stated and implied needs of the customers/users (before designing, manufacturing, and supplying the product) as well as their reactions (after having supplied the product)".

Kent and Taylor (1998) specify five key strategies to build dialogic communication on the web. These can be reinterpreted as factors to create a successful website:

1. The organization needs to have a feedback loop so that it can provide the information that public needs or desires.

2. Websites should make an effort to include general information valuable for all kinds of public. Publishing historical information is not new but "content is what should drive an effective website, and not the fancy graphics that many web sites currently rely upon". 
3. Websites should contain features that make them attractive for repeating visits. Updated information, changing issues, and special forums are some examples.

4. The contents should be well-organized and hierarchical. Like the second factor, authors insist on that the content should be textual rather than graphical although today many experts agree that graphics and textual design must have a balance.

5. About the links to other sites, Kent and Taylor (1998) warn the web designers that offering outer links is usually preferred because of "goodwill" but it might be a handicap as the visitors may never get back to the website. They recommend that web sites should include only essential links with clearly marked paths for visitors to return to the site (Kent $\&$ Taylor, 1998, p.330).

Eschenfelder, Beachboard, McClure, and Wyman (1999) published the criteria used to assess the design and management of the U.S. federal government websites. Smith (2001) adapted these criteria of website design from Eschenfelder et al. (1999) to evaluate five governmental websites in New Zealand. In both studies, the criteria were grouped under two headings as information content and ease-of-use. The former, which has 7 or 8 subcategories, refers to the nature of the information, mentioning of the services provided by that website, the accuracy of the web information, privacy of the user, and the use of updated sources as well as data on the website. The latter, having 5 subcategories, is related to links, feedback, accessibility, design, and navigability of the website content. Table 1 shows the criteria specified in the mentioned studies.

Table 1. Comparison of the Website Design and Evaluation Criteria

\begin{tabular}{|c|c|}
\hline Criteria used by Smith (2001) & $\begin{array}{l}\text { Criteria used by Eschenfelder, } \\
\text { Beachboard, McClure, and } \\
\text { Wyman (1999) }\end{array}$ \\
\hline 1 Information Content & 1. Information Content \\
\hline $\begin{array}{l}\text { 1.1. Orientation to website ( } 7 \text { criteria): It includes the mission } \\
\text { and scope of the website, liability statement, services provided } \\
\text { by the website, instructions to use and the news alerts. }\end{array}$ & $\begin{array}{l}\text { 1.1. Orientation to website ( } 7 \\
\text { criteria) }\end{array}$ \\
\hline $\begin{array}{l}\text { 1.2. Content ( } 10 \text { criteria): It includes matching the mission and } \\
\text { the needs of the audience, balanced amount of information, } \\
\text { having direct information. It includes criteria about clear, } \\
\text { consistent, unbiased, and professional use of language. }\end{array}$ & 1.2. Content (12 criteria) \\
\hline $\begin{array}{l}\text { 1.3. Currency ( } 3 \text { criteria): This is about the updated content with } \\
\text { the identified updating periods. }\end{array}$ & 1.3. Currency (3 criteria) \\
\hline $\begin{array}{l}\text { 1.4. Metadata ( } 4 \text { criteria): It includes clear headings, } \\
\text { appropriate metatags and consistent use of terminology as well } \\
\text { as layouts with the headings. }\end{array}$ & $\begin{array}{l}\text { 1.4. Bibliographic Control ( } 5 \\
\text { criteria) }\end{array}$ \\
\hline $\begin{array}{l}\text { 1.5. Services ( } 3 \text { criteria): Availability of services which are } \\
\text { operational and relevant to the user's needs }\end{array}$ & 1.5. Services (4 criteria) \\
\hline $\begin{array}{l}\text { 1.6. Accuracy ( } 4 \text { criteria): It refers to real information as well as } \\
\text { having the sources cited and the accurate use of grammar, } \\
\text { spelling and no mistakes of typing. }\end{array}$ & 1.6. Accuracy ( criteria) \\
\hline $\begin{array}{l}\text { 1.7. Privacy ( } 3 \text { criteria): Users' privacy rights and encrypted } \\
\text { exchange of information are comprised under this heading. }\end{array}$ & 1.7. Privacy (3 criteria) \\
\hline $\begin{array}{l}\text { 1.8. External recognition ( } 3 \text { criteria): Ways in which the value of } \\
\text { the site is recognized by users such as awards and reviews } \\
\text { besides the number of links. }\end{array}$ & \\
\hline
\end{tabular}




\begin{tabular}{|l|l|}
\hline 2. Ease-of-Use Criteria & 2. Ease-of-Use Criteria \\
\hline $\begin{array}{l}\text { 2.1. Links (6 criteria): Updated links, shortcuts, warnings about } \\
\text { the links or links to other relevant pages are mentioned in this } \\
\text { subsection. }\end{array}$ & $\begin{array}{l}\text { 2.1. Quality of links (9 criteria): } \\
\text { Speed of links and minimal use of } \\
\text { bright colors and large graphics } \\
\text { are also included in this } \\
\text { subsection. }\end{array}$ \\
\hline $\begin{array}{l}\text { 2.2. Feedback Mechanisms (5 criteria): Contact details for } \\
\text { entity, data forms and instructions for the user are included. }\end{array}$ & $\begin{array}{l}\text { 2.2. Feedback Mechanisms (2 } \\
\text { criteria): }\end{array}$ \\
\hline $\begin{array}{l}\text { 2.3. Accessibility (6 criteria): Speed of response, easy and rapid } \\
\text { access to the website, publishing on the search tools, backlink } \\
\text { to the entity and using not a complex URL which is not open to } \\
\text { confusion }\end{array}$ & 2.3. Accessibility (4 criteria) \\
\hline $\begin{array}{l}\text { 2.4. Design (7 criteria): Functional format and graphic design, } \\
\text { consistent format through website, use of Standard HTML, use } \\
\text { of higher level technology such as frames and Java Script, use of } \\
\text { downloadable small-size images and documents }\end{array}$ & $\begin{array}{l}\text { 2.4. Design (11 criteria): More } \\
\text { detailed criteria of graphics use } \\
\text { are included here. Another } \\
\text { criterion about attention-getting } \\
\text { devices like use of bold, italics } \\
\text { and blinking is seen in this } \\
\text { subsection. }\end{array}$ \\
\hline $\begin{array}{l}\text { 2.5. Navigability (7 criteria): This subsection includes logical } \\
\text { organization of the website, use of conventional navigation } \\
\text { models with options and facilitated type of browsing as well as } \\
\text { providing search engine. }\end{array}$ & $\begin{array}{l}2.5 \text {. Navigability (7 criteria) } \\
\end{array}$ \\
\hline
\end{tabular}

Source: Smith (2001) and Eschenfelder et al. (1999).

In two other studies, a positive website design has been assessed through different aspects. Kim, et al. (1999) surveyed on health-related websites and peer-reviewed journals to find out common criteria which were being benefited for designing websites on health issues. They included 13 criteria which were rated by the participants. Dragulanescu (2002), however, implemented Total Quality Management tools to make questions for the users to answer about the perfect-like web design which meets the basic needs or desires of web users. Thus, this differs from the others with its focus on the viewpoint of users rather than considering designers' or service providers' perceptions. Table 2 compares the criteria revealed by these two studies.

Table 2. Comparison of the Website Design Criteria of Health-Related Web Design and UserFocused Criteria

\section{Criteria proposed by Kim et. al. (1999)}

- Content: Quality, reliability, accuracy, depth)

- Design and aesthetics: Layout, interactivity, graphics, use of media

- Disclosure of authors, sponsors, and developers

- Currency of information: Frequency of updates

- Authority of source: Reputation of source, trustworthiness

\section{Criteria proposed by Dragulanescu (2002)}

- Accuracy: The extent / degree of information, its exactness and correctness

- Authority: The extent / degree to which the author could be considered an expert in his / her field.

- Coverage: The extent / degree to which topics were observed, analyzed, and reported

- Currentness: The extent / degree to which the distributed information belongs to the time in progress

- Density: The extent / degree to which comprehensive and relevant information is displayed on the webpage 
- Ease of use: Usability, navigability)

- Accessibility and availability

- Links

- Correct documentation: presentation of clear references

- Intended audience

- Contact addresses/feedback mechanism

- User support

- Miscellaneous

Source: Adapted from Kim, et al. (1999, p.648) and Dragulanescu (2002, p.253).

Studies about guidelines for making successful university or college websites are a few. Borges, Morales, and Rodriguez (1999; cited in Zhang \& von Dran, 2000, p.1254) adapted Nielsen's guidelines to evaluate 10 university websites and performed user tests on them. Zhang and von Dran (2000) implemented Herzberg's theory to assess web design to test evaluation on a two-factor model. They formed questions related to features 12 criteria which were grouped under two factors. The questions were replied by a selected group of university students. The two factors they called were hygiene and motivator factors.

Pinto et al. (2009) assessed the information provided by Spanish universities on their websites regarding accreditation procedures. They used metric analysis and SWOT analysis as the methodology. The essential structure was based on 7 main criteria on 70 indicators not equally distributed among all. The visibility of information, correctness and completeness had the greatest number of indicators while authority, updatedness, accessibility, quality assessment, and navigability were the other five criteria to be assessed.

Table 3. Criteria of the Survey on Website Design and Evaluation

\begin{tabular}{|l|l|}
\hline Criteria to evaluate the websites & Number of survey questions / Sub-criteria \\
\hline User perceptions & Q1-Q2-User interest \\
& Q3-Manipulative manner \\
& Q4-Trustworthiness of the website \\
& Q6-User satisfaction \\
\hline Accuracy & Q5-Accuracy of information \\
\hline Consistency & Q7-Consistency of quality \\
& Q20-Consistency of layout \\
& Q25-Consistency of translation \\
\hline Design & Q8-Plainness \\
& Q9-Metadata ( hierarchical order of menus) \\
& Q10-Q11-Q12-Visual-textual balance \\
& Q13-Vividness \\
& Q14-Corporate images and colors \\
& Q15-Graphics design \\
& Q16-Audio-visual format \\
\hline Content & Q17-Q27-Being informative \\
& Q18-Transparency \\
& Q22-Categorizing information \\
& Q17-Q23-Q26-Use of PR elements \\
\hline
\end{tabular}




\begin{tabular}{|l|l|}
\hline Currency & Q19-Updatedness \\
\hline Ease-of-use & Q21-Q30-Accessibility of services \\
\hline Feedback mechanisms / Interactivity & Q24-Student feedback \\
& Q28-Contact information \\
& Q29-Server-side scripting \\
\hline
\end{tabular}

As the above mentioned review of the literature shows, all aspects of websites are currently studied by researchers so as to enhance their potentials in informing users and visitors. This need is also pressing in Turkey where the Internet is currently used for attaining information about locates and contexts that are difficult to reach physically. Hence, this study aimed to collect the opinions of English or related majors (such as English language teaching, English linguistics, English language and literature, English translation studies, American language and literature) about their university's or department's websites.

\section{Methods}

\section{Participants}

One hundred and twenty-five students from state universities from cities of Tekirdag, Ankara, Istanbul, Izmir, Antalya and Diyarbakir participated in our study. Since most of the web content indexed is English, it is expected of the universities to provide an English version of its website as well. This fact is one of the reasons for us to send questionnaires to those with a command of English. Secondly, learning a foreign language is an imaginatively and cognitively enriching experience, and helps learners see matters or events from multiple perspectives. Besides, their youth suggests their familiarity with technology. Since most of them are females, it is thought that they have been sensitive to the dimension of design.

\section{Instrumentation}

For the survey used in this study to evaluate website design, 30 questions have been prepared depending on various aspects of 8 criteria. The 8 main criteria have 24 sub-criteria with varying rates in total. As mentioned before, Table 3 shows these criteria with the sub-criteria for each one and the number of every individual question assessing that sub-criterion.

The criteria of accuracy, design, content, currency, ease-of-use and feedback mechanisms/ interactivity exist somehow in earlier studies in the literature. However, rather than measuring the users' viewpoints, most of the former studies have been based on the criteria significant for web designers or the executives of organizations as being the publishers of their websites. Furthermore, only a few studies have focused on how to improve university websites. Therefore, assessing what university students think about the website of a higher education institution is one of the primary objectives of this study. User perceptions with the four related sub-criteria endeavor to assess to what extent user interest, the manipulative manner of the organization, trustworthiness of the website as a source of information and the general user satisfaction contribute to the success of a website.

The design criterion has 7 sub-criteria including plainness, metadata, visual-textual balance, vividness, the use of corporate images and colors, graphics design and audio-visual format. The 
metadata called as 'bibliographic control' in Eschenfelder et al. (1999), is one of the subcriteria related to web design in our study. Accuracy like in Smith (2001) denotes the accuracy and reality of released information. Currency, as one of the basic criteria of all studies, mentions how much updated information is used on the web. Ease-of-use, like in Kim et al. (1999), has been included as a main criterion. In the survey of website design evaluation, it is accepted as the accessibility of organizational services on the Internet while having a broader sense in the resume evaluation survey with the sub-criteria of accessibility and navigability.

Consistency is one of the main criteria in website design evaluation. It refers to consistency of the quality both on the homepage and on the related departmental websites. It also refers to the consistency of layout and the consistency of translation of Turkish website into foreign languages.

The content here has a narrower meaning for it indicates the characteristics of the information released. It has four sub-criteria of being informative, transparent, categorical, and including elements of public relations with the focus of publicity in general.

Parallel to the current tendencies, interactivity is accepted as one of the basic criteria for the study. Interactivity is named as "feedback mechanisms" by Smith (2001) and Eschenfelder et al. (1999). That is because three questions have direct emphases on acquiring student feedback, publishing contact information to have general feedback and using server-side scripting to make feedback process easier.

The second survey, which aims to evaluate the quality of academic resumes, has fewer criteria. There are three main criteria as content, design and ease-of-use. Table 4 reveals the sub-criteria and questions evaluating each one.

Table 4. Criteria of the Survey on Academic Resume Evaluation

\begin{tabular}{|l|l|}
\hline Criteria for academic resumes & Number of survey questions/ Sub-criteria \\
\hline Content & Academic services and products \\
& Q1-Publications \\
& Q2-Q10-Q11-Courses offered \\
& Q3-Research interests \\
& Q4-Oral presentations \\
& Q10-Q11-Theses supervised \\
\cline { 2 - 3 } & Academic competence and skills \\
& Q5-Q6-Linguistic(L2) competence \\
& Q7-Academic competence \\
\cline { 2 - 3 } & Personal information \\
& Q12-Q13-Q14-Age, marital status, hobbies \\
& Q8-Q9-Memberships \\
\hline Design & Q15-Visual format \\
& Q20-Textual format \\
& Q21-Downloadable file formats \\
\hline Ease-of-use & Q16-Accessibility of services \\
& Q17-Q18-Q19-Navigability \\
\hline
\end{tabular}

The content here is again related to the information content in resumes while focusing on three different kinds of data. Academic services and products with 5 sub-criteria, academic 
competence and skills with 3 sub-criteria and personal information with 3 sub-criteria comprise various aspects of the content.

Similar to the survey of evaluating the design of websites, design criterion is based on textual and visual formats used in the resumes. A third sub-criterion is added to this survey to check the importance of using downloadable file formats. As mentioned before, ease-of-use indicates the accessibility and navigability of the web sources while questioning the relevance of having links to external websites.

Stating more specifically, the questionnaire used in this study included two parts containing 30 items related to university web site in general and 24 to resumes in particular. The survey asked the participants to rate each of the items following on a 1-5 Likert Scale (Strongly agree, Agree, Neutral, Disagree, Strongly disagree). SPSS was used to find out mean scores (along with standard errors and standard deviations) of the items. They ranged from relationship between the effect of a website and the choice of a university to details regarding the information content, layout, and design of the website in general.

The preparation process of the questionnaire started over a year ago, and it has been finalized just before its distribution of the questionnaire used in our study (actually a pilot questionnaire was administered but due to the problems related to its timing, the results were not evaluated). Professional experts' ideas were important, therefore the Web Marketing Association was e-mailed. William Rice, the president, informed that they evaluated all of their websites on the items of design, innovation, content, technology, interactivity, copywriting, and ease of use on a scale of ten (W. Rice, May 4, 2009). The association has been evaluating the universities submitted for web awards (the reader can see their report on the 1,092 sites submitted to the WebAwards in 2010 in our 24 page Attributes of an Award Winning Website Study).

In this study, the feedback about the quality and comprehensiveness of the items were obtained from unstructured interviews with the staff of IT departments, press offices, computer teaching departments, an employee of the Ministry of Culture, and academics actively involved in web design and students' ideas. Web sites of various universities in Turkey were analyzed as well. The questionnaire was made accessible online, and the link was sent online to the participants by mail and by using social network sites' interest groups.

The Cronbach's alpha coefficient of the scale was found to be .927 indicating a relatively high internal consistency of the items. The narration and explanation of the data were as follows: $A$ cut-off point was determined for convenience and ease of reading. The means equal to or above 4.3 (in the tables, those typed in bold) indicated a threshold for good agreement for item whereas those equal to or below 3 (in the tables, those given in italics) was considered to have a lower importance given by the students for the item in question.

\section{Findings}

Though lower than the mean score of 4.3 , the first item deserves special attention since majority of the students claim to be checking the websites of their future universities before deciding to apply. When they gave their opinion on whether the website of a department had an effect on their decision, they tended to disagree on the effect of the web site in choosing 
their department (2.72). However, these results suggest that they give importance to the functions or potential influence of a university website in forming students' opinions who seek for information about their future schools.

Table 5. Students' Opinions of University's and Departments' Websites

\begin{tabular}{|c|c|c|c|c|}
\hline & Items & Mean & St Err. & St Dev. \\
\hline 1 & $\begin{array}{l}\text { I investigate the home page (opening page) of the } \\
\text { university before choosing it for application. }\end{array}$ & 3,9120 & 11303 & 1,26374 \\
\hline 2 & $\begin{array}{l}\text { Prior to application to a university, I investigate the web } \\
\text { site of the department. }\end{array}$ & 3,7760 & 11122 & 1,24346 \\
\hline 3 & $\begin{array}{l}\text { The home page (opening page) of the university is/was } \\
\text { effective on the question to whether or not to apply for } \\
\text { the university. }\end{array}$ & 3,0080 & 10746 & 1,20145 \\
\hline 4 & $\begin{array}{l}\text { The web site of a department is / was effective on } \\
\text { whether or not to choose it for application. }\end{array}$ & 2,7200 & 10632 & 1,18866 \\
\hline 5 & $\begin{array}{l}\text { The web sites of the educational institutions give ideas } \\
\text { about the quality of the education given there. }\end{array}$ & 3,6400 & 09732 & 1,08806 \\
\hline 6 & I am/was content with the web site of my university. & 3,4720 & ,10929 & 1,22195 \\
\hline 7 & $\begin{array}{l}\text { There should be no difference as to the quality of the } \\
\text { home page (opening page) and the sites of departments. }\end{array}$ & 4,3920 & 07440 & ,83179 \\
\hline 8 & $\begin{array}{l}\text { The home page (opening page) of web site should be } \\
\text { plain. }\end{array}$ & 3,5200 & 09477 & 1,05952 \\
\hline 9 & $\begin{array}{l}\text { Web site should have clear and hierarchically structured } \\
\text { submenus. }\end{array}$ & 4,5600 & 05611 & ,62733 \\
\hline 10 & $\begin{array}{l}\text { There should be a balance between visual and textual } \\
\text { elements. }\end{array}$ & 4,3120 & 06855 & ,76639 \\
\hline 11 & $\begin{array}{l}\text { Web site should have visual elements rather than textual } \\
\text { ones. }\end{array}$ & 3,0080 & 08980 & 1,00399 \\
\hline 12 & $\begin{array}{l}\text { Web site should have textual elements rather than visual } \\
\text { ones. }\end{array}$ & 2,8960 & 09216 & 1,03038 \\
\hline 13 & Web site should have a variety of colors. & 3,5520 & ,08905 & 99560 \\
\hline 14 & $\begin{array}{l}\text { Web site should use the logo and theme colors of the } \\
\text { university. }\end{array}$ & 3,9360 & ,08092 & 90468 \\
\hline 15 & Web site should have animations. & 3,3040 & 09852 & 1,10149 \\
\hline 16 & Web site should have music and sound effects. & 3,0800 & ,11393 & 1,27381 \\
\hline 17 & Web site should have an introductory video. & 4,5200 & 06584 & ,73616 \\
\hline 18 & $\begin{array}{l}\text { Web site should provide the institutional information in a } \\
\text { transparent manner. }\end{array}$ & 4,4880 & 06077, & 67937, \\
\hline 19 & $\begin{array}{l}\text { Attention should be paid attention to the update the web } \\
\text { site. }\end{array}$ & 4,7280 & ,05492 & 61403, \\
\hline 20 & $\begin{array}{l}\text { The sites connected to the home page should be in the } \\
\text { same format as the opening page. }\end{array}$ & 4,2880 & 08410 & 94028 \\
\hline 21 & $\begin{array}{l}\text { Web site should contain announcements and news } \\
\text { archive, and this archive should be easily accessible. }\end{array}$ & 4,7120 & 04927, & 55089 \\
\hline 22 & $\begin{array}{l}\text { There should be separate sections for announcements } \\
\text { each with relevant content for the student, the } \\
\text { academician or the general viewer. }\end{array}$ & 4,3760 & 07842 & 87680 \\
\hline
\end{tabular}




\begin{tabular}{|c|l|c|c|c|}
\hline 23 & $\begin{array}{l}\text { A press and media section should be constituted for the } \\
\text { news related to the university in the press and media. }\end{array}$ & 4,2400 &, 06947 &, 77668 \\
\hline 24 & The web site should have a student portal. & $\mathbf{4 , 4 7 2 0}$ &, 06679 &, 74678 \\
\hline 25 & $\begin{array}{l}\text { The Turkish content in the home page and the } \\
\text { department sites should take place in the English web } \\
\text { page as well. }\end{array}$ & $\mathbf{4 , 4 8 0 0}$ &, 06486 &, 72513 \\
\hline 26 & $\begin{array}{l}\text { Web site should have elements aimed for promoting the } \\
\text { university rather than providing information about it. }\end{array}$ & 2,6160 &, 08015 &, 89608 \\
\hline 27 & $\begin{array}{l}\text { Web site should have elements aimed for providing } \\
\text { information about the university rather than promoting } \\
\text { it. }\end{array}$ & 3,8160 &, 07482 &, 83651 \\
\hline 28 & $\begin{array}{l}\text { The home page and sites connected should have the } \\
\text { email addresses of the units concerned. }\end{array}$ & $\mathbf{4 , 5 4 4 0}$ &, 05623 &, 62867 \\
\hline 29 & $\begin{array}{l}\text { To send a message to the unit(s) concerned, the web site } \\
\text { should have a message box on the screen. }\end{array}$ & $\mathbf{4 , 4 4 8 0}$ &, 05843 &, 65323 \\
\hline 30 & $\begin{array}{l}\text { If the university has its own radio station, it should } \\
\text { broadcast from the site. }\end{array}$ & 4,2400 &, 07903 &, 88354 \\
\hline
\end{tabular}

As seen in Table 5, following points deserve special attention since these results constitute what students demand in that;

- web sites are updated regularly (4.72)

- an announcements section and an easily accessible section for news archive is available (4.71)

- submenus are clear and hierarchically structured (4.56)

- $\quad$ email addresses are shared (4.54)

- an introductory video of the university/ department is uploaded (4.52)

- information about the university is transparent (4.48)

- content is available in English (4.48)

- a message box is available to visitors to send messages to specific units (4.44)

- a student portal is available (4.47)

- the home page (opening page) of the department and that of the university are similar in quality (4.39)

- specific announcements sections are available for target viewers: one for the academics, one for the students and one for the general viewer (4.37)

- there is balance between the textual and the visual (4.31), the textual is not dominant over the visual (2.89)

Table 6. Students' Opinions of the Web-based Information Related to Their Departments' Instructors

\begin{tabular}{|c|l|c|c|c|}
\hline & The resumes of the academics should have & Mean & St Err. & St Dev. \\
\hline 1 & Information related to articles published. & $\mathbf{4 , 4 1 6 0}$ &, 06444 &, 72048 \\
\hline 2 & Information related to courses given & $\mathbf{4 , 5 5 2 0}$ &, 06570 &, 73458 \\
\hline
\end{tabular}




\begin{tabular}{|r|l|r|r|r|}
\hline 3 & Information related to his/her research field. & $\mathbf{4 , 4 8 8 0}$ &, 06285 &, 70271 \\
\hline 4 & Information related to his/her presentations & 4,2720 &, 07307 &, 81692 \\
\hline 5 & Information related to their foreign language levels & 4,0800 &, 08160 &, 91228 \\
\hline 6 & $\begin{array}{l}\text { Their grades for examinations indicating their foreign } \\
\text { language proficiency }\end{array}$ & 3,5040 &, 11338 & 1,26761 \\
\hline 7 & Grades for academic examinations like ALES, GRE, GMAT & 3,4400 &, 11438 & 1,27886 \\
\hline 8 & $\begin{array}{l}\text { Information related to their membership at scientific } \\
\text { institutions }\end{array}$ & 4,0560 &, 08447 &, 94446 \\
\hline 9 & $\begin{array}{l}\text { Information related to their membership at social } \\
\text { institutions }\end{array}$ & 3,6240 &, 09946 & 1,11199 \\
\hline 10 & Information related to projects they manage or participate & $\mathbf{4 , 3 4 4 0}$ &, 06335 &, 70829 \\
\hline 11 & $\begin{array}{l}\text { Information related to MA and PhD theses they have } \\
\text { supervised }\end{array}$ & $\mathbf{4 , 3 7 6 0}$ &, 06688 &, 74773 \\
\hline 12 & Information related to their age & 2,9520 &, 10464 & 1,16989 \\
\hline 13 & Information related to their marital status & 2,4160 &, 10044 & 1,12296 \\
\hline 14 & Information related to their hobbies and interests & 3,0560 &, 10430 & 1,16608 \\
\hline 15 & Their updated photographs & 3,7040 &, 09573 & 1,07030 \\
\hline 16 & $\begin{array}{l}\text { Office hours assigned to meet with students accessible } \\
\text { through the web }\end{array}$ & $\mathbf{4 , 4 4 0 0}$ &, 06947 &, 77668 \\
\hline 17 & $\begin{array}{l}\text { Links to their publications (proceedings, article, sections in } \\
\text { a book, books) }\end{array}$ & $\mathbf{4 , 4 8 0 0}$ &, 06584 &, 73616 \\
\hline 18 & Links to a mail group if there is any & $\mathbf{4 , 4 0 0 0}$ &, 06222 &, 69561 \\
\hline 19 & $\begin{array}{l}\text { Links to the academics' membership at social networking } \\
\text { sites }\end{array}$ & 3,3760 &, 11565 & 1,29306 \\
\hline 20 & $\begin{array}{l}\text { Links to the academics' membership at social networking } \\
\text { sites }\end{array}$ & 3,9760 &, 08833 &, 98754 \\
\hline 21 & $\begin{array}{l}\text { The feature allowing to download them both in word and } \\
\text { PDF format. }\end{array}$ & 3,4560 &, 10442 & 1,16746 \\
\hline
\end{tabular}

Students' main priority is the updates regularly made by websites to change their content. The second highest mean score is to do with availability of two sections for both announcements and the news archive with easy access. Being aware of current announcements is necessary to facilitate the availability of up-to-the-minute information. The very dimension of current announcements is closely related to updated look. With past announcements archived in a separate section, the site avoids overload of information. The items addressing the usability of e-mail addresses and message box in the first section and the office hours and mails groups in the resume section reflect the demand on their part for instructors communicating and interacting with them.

Preference for the information-based promotional content indicates that students do not want their university to associate a commercial image in its pejorative sense, which, if it had, would do harm to their employment outcomes. In other words, a representation of their university is that of theirs. Enthusiasm for representation is implied in student portals as well. They suggest active, autonomous participation through which they are constructive agents of the institution of higher education. Another major item to attach importance is the expressed need for an introductory video broadcast on the web site, in which the students as well as professors may be shown highlighting the advantages of their education in their university. 
The item regarding the English equivalence of the Turkish website may indicate a bias as the participants are English major or related majors. Nevertheless, apart from that possibility, it is a fact that many web sites do not include many important sections addressing international students and foreign academics seeking research partnership, such as announcements that might help international prospective students and other content with potential for relevancy. The translation is also deficient in terms of use of natural English, and lack of cross-linguistic equivalence for specialized terminology sometimes to the point of negative products of machine translation. Another interesting information is the availability of irrelevant content overloaded with legal terms (law number of a regulation). In the resume section, the emphasis is on the need for the following ( 8 agreed and 2 disagreed items out of 21):

- information related to the articles written (4.41),

- courses offered (4.55),

- their research field/interests (4.48),

- projects conducted or participated (4.34),

- Master's and doctoral theses supervised (4.37),

- office hours assigned for meetings with the students (4.44),

- links to their publications (4.48)

- their mail groups (4.40).

These results suggest that students attach the least importance to those information pieces related to their instructors' age and marital status although some departments advertise such status the reason of which remains undisclosed. Many mean scores in resume section are expected. One of the more interesting ones is that for the item to do with master's and doctoral theses supervised. This item is important for those keen on research or in pursuit of a research career. Research makes a university a high-ranked one. In terms of competing for jobs, postgraduate education gains importance to make students stand out amongst the undergraduates, whose numbers increased.

\section{Conclusions and Implications}

Tasks related to website development are important. According to Thelwal, Binns, Harries, Page-Kennedy, Price, and Wilkinson, (2007), a university website provides scholarly and pedagogical information. Secondly, it functions "as a marketing tool for prospective students about the courses available and the university itself. Third, it contains "information about the research conducted at the university, including details of active scholars, groups, and projects" (Thelwal, et al., 2007, p.95). Once indexed by a search engine, the university website not only facilitates international collaboration of academics seeking research partners home and abroad but also introduces itself as an alternative choice for students, both home and overseas, with an international appeal. Given the steady economic growth of Turkey, the Turkish government should allocate funds for projects related to the scope and quality of the websites of Turkish universities so that they use the Internet to get broader recognition.

In the future, communicative tasks related to university web designs would encourage them to participate more actively in their learning processes. However, it is our observation that 
students do not participate actively in processes in learning English in or out of class. It is not innate, but just the way they have been socialized to study or learn. However, the more involved a learner is, the better they will learn (involvement load hypothesis; Hulstijn \& Laufer, 2001). An interesting idea would be involving them as active contributors in the coconstruction of the website of their school. A web task might involve learners' sensitivities to issues of discourse such as genre and register along with non-linguistic features (audio and/or visual) or cognitive load embedded in the teaching materials. They could gain sociolinguistic dimensions of vocabulary from this relevant kind of task-induced involvement could benefit from (involvement load hypothesis; Hulstijn \& Laufer, 2001). Another point worth to mention is that most of the English or related majors are women, who can contribute especially to visual aspects of design. According to Franklin, a professor of educational studies, instructional technology (personal communication, May 25, 2011), women are very good at visualization of images, which she witnessed in hiring females as designers, and they are large users of Internet in any culture (except the closed ones, where their access is denied).

As for the process related to design, it can also be an imaginatively enriching experience with gift of looking at matters from different perspectives. It would be enriching in terms of the existing literature on websites as well which reminds us of Derrida's famous quote "everything is text". The web related tasks may provide job opportunities. Whether English or related majors pursue a teaching career or not media literacy is a good asset for them. One of the most important features students are the most active producers is student portals, which, in Franklin's words (personal communication, May 25, 2011) is the next hot thing in USA. After all, learners are expected to participate in their learning processes in US or UK school settings; it is a part of learning culture in these contexts, which is also expected of learners of English to be aware of as a part of intercultural competence. The way the questionnaire was responded suggested an idea on involvement or participation. In the case participation in works requiring multiple disciplines, our study has implications for promising collaboration of English majors with other majors professionally (professional web designers, bloggers, advertisers, journalists, etc.) as well as academically through the implementation of interdisciplinary studies or double majors (e.g. CEIT and ELT).

We hope that our study might influence ESL teachers to entertain the thought of benefiting from web tasks for themselves and students. Wondering if TBLT might work for "teachers and learners in the classroom as it does for SLA research", van den Branden (2006) underlines the lack of empirical research conducted on the use of tasks as "basic units for the organization of educational activities in intact language classrooms" (p.1). Whether web development tasks may be evaluated in classrooms effectively in task-based language teaching approach (TBLT) may be investigated in future research, though we should be aware of the distance between rhetoric and the realities, as Nunan is reported in Feeney's book review (2006) to caution us against in comment on the increase on the number of the textbooks based on TBLT.

\section{References}

Dragulanescu, N. G. (2002). Website quality evaluations: Criteria and tools. International Information and Library Review, 34, 247-254.

Feeney, A. (2006). Review of the book Task-Based Language Teaching. ELT Journal, 60(2), 199201. 
Hulstijn, J. H. \& Laufer, B. (2001). Some empirical evidence for the involvement load hypothesis in vocabulary acquisition. Language Learning, 51(3), (539-558).

Kent, M.L., \& Taylor, M. (1998). Building dialogic relationships through the World Wide Web, Public Relations Review, 24(3), 321-334.

Kim, P., Eng, T. R., Deering, M.J., Maxfield, A. (1999), Information in practice: Published criteria for evaluating health related web sites. BMJ, 318(6), 647-649.

Nunan, D. (2004). Task-based language teaching. Cambridge: Cambridge University Press.

Ohlund, B., Ho Yu, C., Jannasch-Pennell, A., \& DiGangi, S. A. (2000). Impact of asynchronous and synchronous Internet-based communication on collaboration and performance among K-12 teachers. Journal of Educational Computing Research, 23(4), 405-420.

Pinto, M., Guerrero, D., Fernandez-Ramos, A., Doucet, A. V. (2009). Information provided by Spanish university websites on their assessment and quality processes. Scientometrics, 81(1), 265-289.

Smith, A. G. (2001). Applying evaluation criteria to New Zealand government websites. International Journal of Information Management, 21, 137-149.

Thelwall, M., Binn, R., Harries, G., Page-Kennedy, L.P., Wilkinson, D. (2002). European Union associated university websites. Scientometrics, 53(1), 95-111.

Timisi, N. (2003). Yeni iletişim teknolojileri ve demokrasi, Ankara: Dost.

YOK. (2011). Turkish university lists. Retrieved on 15 May 2011 from http://www.yok.gov.tr/ content/view/527/222/lang,tr/

van den Branden, K. (2006). Introduction: Task-based language teaching in a nutshell. In V. D.

B. Kris (Ed.): Task-based language education (pp. 1-17). Cambridge: Cambridge University Press.

Zhang, P., Von Dran, G.M. (2000), Satisfiers and dissatisfiers: A two-factor model for website design and evaluation. Journal of the American Society for Information Science, 51(14), 1253-1268.

Correspondence: Bugra Zengin, Assistant Professor, Department of Western Languages and Literatures, Faculty of Science and Letters, Namik Kemal University, Tekirdag, Turkey 